„Tehetség, szorgalom, hivatás”

\author{
Tanulmánykötet
}

Kézirat lezárva: 2021. június 25. 
Kiadja:

a Magyar Rendészettudományi Társaság

Vám- és Pénzügyőri Tagozata

Szerkesztette:

Csaba Zágon és

Zsámbokiné Ficskovszky Ágnes

Felelős kiadó:

Szabó Andrea

ISBN: 978-615-81879-0-9

A mú szerzői jogilag védett. Minden jog, így különösen a sokszorosítás, terjesztés és fordítás joga fenntartva. A mű a kiadó írásbeli hozzájárulása nélkül részeiben sem reprodukálható, elektronikus rendszerek felhasználásával nem dolgozható fel, azokban nem tárolható, azokkal nem sokszorosítható és nem terjeszthetô. 
Szerzők

Lektorok

Lectori Salutem!

Tanulmányok

Christián László - Lippai Zsolt: Kakukktojás vagy új rendészeti alappillér?

Gonda Éva: Az Europol hospitáció hasznosítása a pénzügyi nyomozók képzése terén

Kakócz Krisztián - Vedó Attila: A toloncolás szabály- és szervezetrendszere a második világháború előtt

Kovács Gábor: A vezetői kompetenciák fejlesztésének lehetőségei a Rendészettudományi Kar hallgatóinak körében

Magasvári Adrienn: Egy új jogviszony „születése” - az adó- és vámhatósági szolgálati jogviszony vizsgálata ..

Molnár Katalin: Mi harminc? Tudománymetria helyett - Szerzőtársas játék................................ 87

Nyeste Péter: A modern bűnügyi hírszerzés modelljeinek fejlődése ............................................ 103

Pajor Andrea: Adóigazgatási tisztviselők képzése .

Sallai János - Borszéki Judit: Egy megvalósítható utópia? Közös munkanyelv keresése a nemzetközi rendőri együttmúködés kezdetén.

Suba László: Nyelvhelyesség a közszférában: Létkérdés vagy úri huncutság?

Szabó Andrea - Hájer Tamara: A vámfelsőoktatás uniós elismerési eljárásának elemei

Szlifka Gábor: Okos adózás, okos adóigazgatás - Minden ami okos, de mit is jelent pontosan?

Kutatási eredmények

Balla József - Kiss Lajos: A rendvédelmi szervező szakirányú továbbképzési szak indításának legfontosabb tapasztalatai.

Borzán Anita - Szekeres Bernadett: A digitalizáció hatása a gazdasági szakismeretek és a számvitel oktatására.

Duchon Jenő: Tanulási stílus és játékos típus összevetése felnőtteknél, az oktatási folyamat játékosítása céljából

Erdős Ákos - Somogyi Ágnes: Koffeinhasználat és koffeinhasználati zavar vizsgálata rendészeti hallgatók körében

Halasi Nóra: Feltáró kutatás a hivatástudat és motiváció jelentőségének vizsgálatára, a Hajdú-

Bihar Megyei Adó- és Vámigazgatóság személyi állományának összefüggésében 251 


\title{
Halasi Nóra*: Feltáró kutatás a hivatástudat és motiváció jelentőségének vizsgálatára, a Hajdú-Bihar Megyei Adó- és Vámigazgatóság személyi állományának összefüggésében
}

\begin{abstract}
Absztrakt
A hivatástudat és a motiváció jelenléte, valamint intenzitása kiemelt jelentőséggel bírnak a mindennapos hivatali munkavégzés során. A hivatástudat szorosan összekapcsolódik az egyén személyiségével, befolyásolhatja a belső érdeklődés, az egyén tapasztalatai, a pályaválasztás indokai és az adott hivatás iránt tanúsított érdeklődés. A munkatevékenység végzése során a szakmai ismeretek és képességek elsajátítása, valamint ezek aktualizálása és fejlesztése, a szakmai elvárásoknak való megfelelés, a szakmai sikerekhez és kudarcokhoz való viszonyulás egyaránt befolyásoló tényezők. Az egyén szakmai önképe folyamatosan változik a szakmai identitással összekapcsolódva, mely hatással bír a szakmai motiváció jelenlétére és mértékére is. Az eredményes munkavégzést nagyban segíti a munkahely iránti elkötelezettség, melynek alapjai a hosszú távú együttmúködés a munkavállaló és a munkáltató között, illetve a munkavállalók szakmai motivációjának fenntartása. A kutatás során online kérdőíves módszert alkalmaztam és 33 értékelhetô választ kaptam. Kutatásom legfontosabb célja, hogy feltárja a hivatástudat, a motiváció, valamint a munkahelyi jóllét és elégedettség jelentőségét és intenzitását a Hajdú-Bihar Megyei Adó- és Vámigazgatóság személyi állományának vonatkozásában.
\end{abstract}

Kulcsszavak: hivatástudat, motiváció, szervezeti elkötelezettség, munkahelyi jóllét, munkahelyi elégedettség

\begin{abstract}
The presence and intensity of professionalism and motivation are significant during everyday office work. Professionalism is connected with the individual's personality and influenced by the inner interest, the individual's experience, the reasons for the career choice and the interest in a given profession. The acquisition of professional knowledge and skills and their updating and development, compliance with professional expectations, and attitudes towards professional successes and failures all influence the performance of work activities. The professional self-image of the individual is constantly changing in connection with the professional identity, which also affects the presence and extent of professional motivation. Organizational commitment helps to work effectively, based on long-term cooperation between the employee and the employer, and maintaining the professional basis of employees. During the research, I used an online questionnaire method and received 33 evaluable responses. The most important goal of my research is to explore the significance and intensity of professionalism, motivation, well-being and satisfaction at work in connection with the employees of the Tax and Customs Directorate of Hajdú-Bihar County.
\end{abstract}

Keywords: professionalism, motivation, organizational commitment, well-being at work, job satisfaction

*Halasi Nóra, NAV Hajdú-Bihar Megyei Adó- és Vámigazgatósága, Kockázatkezelési Osztály, kockázatkezelési referens, https://orcid.org/0000-0002-5979-1340; halasi.nora@,nav.gov.hu 


\section{Bevezetés}

Azokat a munkavállalókat, akik a közszférában helyezkednek el, több objektív és szubjektív tényező befolyásolhatja döntésükben. A közszférában jelentős az igény a megfelelő szakmai végzettséggel rendelkező munkavállalók iránt, amely lényeges objektív tényezőként indokolhatja a munkavállalók döntését. Szubjektív tényezőként a dolgozókat motiválhatja az állandó és biztos munkavégzés jelenléte, a szabályozottabb és kiszámíthatóbb munkakörülmények, illetve jövedelmezési rendszer. A közszféra munkavállalói esetében gyakran fontos motivációs tényező a hivatástudat, a szervezeti elkötelezettség, valamint a munkahelyi elégedettség és jóllét. Mindezek mellett a közszolgálati szervezetek - így a Nemzeti Adó- és Vámhivatal - számára is kihívást jelent a munkaerő megtartása, különös tekintettel az új (Z) generációhoz tartozó munkatársak munkaelvárásainak, munkahelyi preferenciáinak kezelése, a lojalitásuk megteremtése, ahogy Magasvári és Szabó bemutatta egy, szintén a NAV-ot érintô, de az én kutatásomhoz képest egyrészt tágabb (földrajzilag, szervezetileg) más szempontból (életkor/generáció) szűkebb szegmensű kutatásában. ${ }^{590}$

\section{A munkabelyi motiváció}

A motiváció pszichés és a testi tevékenységek kezdeményezésében, irányításában és fenntartásában részt vevő folyamatok összessége. Olyan belső késztetés, amelynek hatására adott módon cselekszünk, de a motivációinkat számos tényező képes befolyásolni, külső és belső tényezők egyaránt. Maga a motiváció több tényezőből áll:

- vágy vagy szükséglet érzése,

- a szervezet aktiválása és irányítása, a vágy vagy szükséglet beteljesítéséhez szükséges viselkedés megválasztása, szabályozása és fenntartása révén,

- a szükséglet érzésének csökkentése. ${ }^{591}$

Mcclelland teljesítményszükségletnek nevezte azt a mentális állapotot, amely pszichés motivációt hoz létre valamilyen cél vagy a kiválóság elérésére. Véleménye szerint a teljesítményszükségleten kívül a kapcsolatszükséglet és a hatalomszükséglet ösztönzi munkavégzésre az embereket. ${ }^{592} \mathrm{~A}$ munkahelyen a vezetók feladata úgy szervezni a feladatokat, hogy az egyes munkavállalóknál ez a három szükséglet közül a nekik leginkább megfelelő kerüljön előtérbe, az adott szükséglet nyerjen kielégülést, ugyanakkor a célteljesítmény se kerüljön hátrányba. A magas teljesítményszükségletű munkavállalók a kihívást jelentő feladatokat kedvelik, elérhető célokkal. Ezeket a dolgozókat elsősorban nem a külső jutalmak motiválják, de ők is örömmel fogadják a jutalmakat és a jó teljesítményért járó pozitív visszajelzéseket. A magas kapcsolatszükségletű dolgozók nem szeretnek versengeni, sokkal inkább az együttmúködés jellemző rájuk, ezért érdemes őket csapatmunkában foglalkoztatni. A magas hatalomszükségletű munkavállalók jól motiválhatóak, ha projektmenedzseri feladatokat kapnak, vagy munkacsoportokat vezethetnek. A hatalomorientált személyeket érdemes arra ösztönözni, hogy vezetőkké váljanak, akik majd segítik beosztottjaikat azok szükségleteik kielégítésében. Összességében, akinek a szükséglete kielégülést nyer, az a munkavállaló lesz elégedett a munkájával és

\footnotetext{
590 MAGASVÁRI Adrienn - SZABÓ Andrea: A Nemzeti Adó- és Vámhivatal munkaerő-megtartó képességének vizsgálata egy speciális célcsoport körében. Magyar Rendészet. 2019/2—3. (2019) pp. 143-162. https://doi.org/10.32577/mr.2019.2-3.8

591 ZIMBARDO, Philip et al.: Pszichológia mindenkinek. Pearson Education, Inc., 2017. p. 11.

592 MCClELland, David Clarence: Human motivation. Scott Foresman, New York, 1985.
} 
motiváltabbá is válik a munkavégzésre. ${ }^{503}$ Fowler megállapítása szerint a motiváció igaz története arról szól, hogy az ember tanulásra született, örökké fejlődni szeretne, és arra vágyik, hogy élvezze a munkáját, produktív legyen, pozitívan tudjon hozzájárulni a világ dolgaihoz és tartós kapcsolatokat építsen fel. Ugyanakkor az ember nem azért törekszik mindezek elérésére, mert erre külső motiváló erők ösztönzik, hanem mert ilyen a természete. ${ }^{594}$

\section{A bivatástudat és a szervezeti elkötelezettség}

A hivatás vagy élethivatás nemcsak a munkatevékenységhez, de az ember egész életvitele, életmódja és életformája lényegéhez kötődik, ezeknek egyik alapvető eleme és lényegi kifejeződése. Az ember az identitása szerint különböző mértékben kapcsolódhat a munkájához és foglalkozásához. Az elkötelezettség már a hivatás választásánál is megjelenik óhaj formájában. Racionális és emocionális elemek egyaránt indokolják a hivatás választását és gyakorlását. Ezek adják az adott pálya iránti identitás magas fokát, a hivatásszeretetet és a hivatástudatot. ${ }^{595} \mathrm{~A}$ tudatosság szintje miatt a hivatás identifikáció szintje különböző lehet. A belső érdeklődés, a szubjektív tapasztalat, amely a pályaválasztást motiválja, valamint a szakmai ismeretek és képességek elsajátítása erősíti a hivatás identifikációját, emellett a követelményekkel való szembenézés, a munkatevékenység, a siker és a kudarc hatására a személy és a hivatás kapcsolata szorossá válik. 596 A hivatástudat a munkához fűződő viszony legmagasabb szintje, ahol a pályával kapcsolatos elvárások belsővé váltak, és a tevékenységet meggyőződés irányítja. A munka során a tevékenység és a személyiség tényleges eszményképe valósul meg az elhivatottság legszorosabb értelme szerint, amely a személy munkáját morálisan elválaszthatatlanná teszi az életétől. ${ }^{97}$

A szervezeti elkötelezettség a vállalat és a munkavállalók viszonyát írja le, alkotóelemei a szervezet céljainak elfogadása, késztetés a szervezet érdekében végzett elhivatott munkára és a szervezeti tagság megőrzése iránti határozott vágy. A szervezeti elkötelezettség a munkával kapcsolatos értékek elfogadásával, belsővé tételével, illetve az ezekkel való azonosulás pszichológiai mechanizmusaival írható le. A magasabb elkötelezettséggel rendelkező dolgozók akkor is a szervezetben maradnak, ha elégedetlenek a munkavégzés egyes aspektusaival. ${ }^{998}$ Egy munkavállaló magas szintű elkötelezettségét jelzi, ha a dolgozó a szervezetben marad, amely a munkáltató számára nagyon előnyős, amennyiben egy hatékony munkaerô kötelezi el magát a szervezet iránt. A szervezeti szocializáció, illetve a speciális szakmai ismeretek és készségek elsajátítása hosszú folyamat, ezért a már a szervezet tagjaként tevékenykedő munkavállalók megtartása mindig költséghatékonyabb és eredményesebb, mint az új tagok alkalmazása. O’reilly és Chatman szerint az elkötelezettség legfontosabb

\footnotetext{
593 ZIMBARDO i. m. (2017) pp. 13-14.

${ }^{594}$ FOWLER, Susan: Motiváció magasabb szinten. HVG Kiadó Zrt., Bp., 2014. p. 59.

${ }^{595}$ NAGY Antal: A hivatástudat és az etika oktatása. 1985. http://acta.bibl.uszeged.hu/18219/1/igytf tudkozl historica 1985 075-078.pdf (Letöltve: 2021. április 28.).

596 VÁRINÉ SZILÁGYI Ibolya: Fiatal értelmiségiek a pályán. Akadémiai Kiadó, Budapest, 1981.; DOMBI Alice:

Tanári minta - mintatanár. APC Stúdió, Gyula, 1999.

${ }^{597}$ Bullough, Robert V. - BAughman, Kerrie: First-year teacher eight years later. Teacher College Columbia University, New York, 1997.

598 PORTER, Lyman William et al:: Organizational commitment, job satisfaction, and turnover among psychiatric technicians. Journal of Applied Psychology, 1974. 59. pp. 603-609.
} 
mutatói a szervezeti tevékenységben való aktív részvétel és a jó teljesítmény. ${ }^{599}$ Ezzel szemben a gyakori késés és hiányzás az alacsony szintű elkötelezettségre utalhat. Ugyanakkor a szervezeti elkötelezettség okai összefüggnek az alkalmazottak viselkedésével, a teljesítmény hatékonyságával, a munkával való elégedettségével, továbbá a munkavállaló felelősségével, illetve az életkorral és a munkahely-birtoklással. 600

\section{A munkahelyi jóllét}

Diener megfogalmazása alapján a jóllét az élet szubjektív értékelését jelenti, amely négy elemből áll: az élettel való elégedettség (az élet globális minősítése), a pozitivi affektivitás (boldogság, öröm és mentális egészség), negatív affektivitás (szégyen, bűntudat és stressz), valamint a szituativ elégedettség (egészség, a munka és a magánélet egyensúlya). ${ }^{601}$ Warr kifejezetten a munkával összefüggésben értelmezte a jóllétet, melynek három jellemző alkotóeleme a munkára jellemző autonómia, a munkahelyi követelmények, valamint a munkahelyi társas támasz. Ezek a tényezôk összefüggenek a munkahelyi jóllét három indikátorával: a munkahelyi elégedettséggel, a munkával kapcsolatos szorongással, továbbá az érzelmi kimerüléssel. A munkahelyi elégedettség és a munkahelyi jóllét szorosan kapcsolódnak egymáshoz, azaz a magasabb munkahelyi elégedettség általában pozitív előjelú munkahelyi jólléttel jár és ennek a fordítottja is igaz. ${ }^{602} \mathrm{~A}$ munka kedvező hatással van az egyének jóllétérzetére. ${ }^{603} \mathrm{Ha}$ a munkatársak jólléte pozitív, ennek következtében javul a produktivitás, a munkamorál, kevesebb lesz a hiányzás, a baleset, a fluktuáció és kisebb a betegségből eredő hiányzási ráta. A dolgozók lojálisabbak, elégedettebbek és elkötelezettebbek lesznek munkaadójukkal szemben, és a szervezetet pozitív munkahelyi légkör jellemzi. ${ }^{604}$

\section{A munkahelyi elégedettség}

A legtöbb ember életében jelentős helyet foglal el a munkája, mely áthatja a munkán kívüli létezését is. Ezért igen fontos, hogy a munkáltató megteremtse a minél megfelelőbb, harmonikusabb és eredményesebb munkavégzés feltételeit, amely a szervezet érdekeivel és céljaival is megegyezik. A munkával való elégedettség fontosságának a szervezet szempontjából többféle oka is létezik. Az egyik morális természetű, hiszen a munkavállalók nagy része élete jelentős részét munkával tölti, ezért a munkaadók erkölcsi felelőssége, hogy olyan körülményeket teremtsenek, amelyben megéri dolgozni. A másik ok a munkaadó saját érdeke, hiszen az elégedett dolgozók a munkahely jó hírét keltik, ezzel növelve a jól képzett munkaerők megszerzésének és megtartásának esélyét (GYÖKÉR, 2001).605

Klein meghatározása szerint a munkával való megelégedettség olyan általános attitűd, amely három területről - a sajátos munkatényezők, az egyéni jellemvonások és a munkán kívüli csoportkapcsolatok területéről - származó számos specifikus attitűd összessége.”"006 Spector

\footnotetext{
599 O’Reilly, Charles A. - CHATMAN, Jennifer: Organizational Commitment and Psychological Attachment: The Effects of Compliance, Identification and Internalization on Prosocial Behavior. Journal of Applied Psychology, 1986. 71. 3. pp. 492-499.

${ }^{600}$ BATEMAN, Thomas - STRASSER, Stephan: A longitudinal analysis of the antecedents of organizational commitment. Academy of Management Journal, 1984. 21. pp. 95-112.

${ }^{601}$ DiEnER, Ed: Subjective well-being. Psychological Bulletin, 1984. 95. pp. 542-575.

602 WARR, Peter: Work, unemployment, and mental health. Clarendon Press, Oxford, 1987.

${ }^{603}$ WADDELL, Gordon - BURTON, A. Kim: Is work good for your health and well-being? TSO, London, 2006.

${ }^{604}$ DEUTSCH Szilvia et al: A jóllétet meghatározó tényezők vizsgálata egészségügyi szakdolgozók körében. Alkalmazott pszichológia. 2015/2. szám, pp. 49-71.

${ }^{605}$ GYÖKÉR Irén: Humánerőforrás-menedzsment. Műszaki Könyvkiadó, Bp., 2001. pp. 54-55.

${ }^{606}$ KLEIN Sándor: Vezetés- és szervezetpszichológia. Edge 2000 Kft., Bp., 2004. p. 345.
} 
megfogalmazásában a munkával való elégedettség annak mértéke, hogy az egyén mennyire kedveli, vagy nem kedveli munkáját. A vezetők a pénzt a dolgozók motiválására, megtartására és a szervezeti célok eléréséhez használják. A fizetéssel való elégedetlenség számos nemkívánatos következménnyel jár, többek között alacsony elkötelezettséghez, érdektelenséghez vezet. ${ }^{607} \mathrm{~A}$ munkával való elégedettség pozitív korrelációban áll a motivációval, a szervezeti magatartással, a szervezeti elkötelezettséggel, a mentális egészséggel és a munkahelyi teljesítménnyel.608 A munkával való elégedetlenség ugyanakkor növeli a hiányzók, a kilépők számát, és a konfliktusok kialakulásának gyakoriságát. ${ }^{609}$ Összességében a munkavállalók elégedettségére való törekvés minden vezető számára meghatározó céllá kell, hogy váljon. Az elégedett dolgozó stabil, a szervezet céljaival azonosulni képes, hatékony munkavégzésre alkalmas és munkatársaira viselkedésével pozitív hatást gyakorló munkaerő-állományt jelent. ${ }^{610}$

\section{Anyag és módszer}

A megkérdezés elsô szakaszában a Minnesota Elégedettségi Kérdôivet alkalmaztam a munkahelyi elégedettség mérésére. ${ }^{611}$ A kérdőív rövidített, húsz itemes változata a munkavégzés 20 különböző területével - többek között a munkafeladatokkal, a munkahelyi vezetôvel és a kompenzációval - történő elégedettségen keresztül ad jellemzést az általános munkahelyi elégedettségre és jóllétre vonatkozóan. A válaszadás egy ötfokú Likert-skálán történik (1 nem vagyok elégedett; 5 - teljes mértékben elégedett vagyok), a válaszadónak a kérdőív kitöltése során a mindennapi munkavégzés különböző területeivel való elégedettség mértékét kell kifejeznie. A kérdőívben szereplő 20 item intrinzik és extrinzik munkahelyi motivációs tényezőknek feleltethető meg. Ryan és Deci meghatározása alapján az extrinził - eszköz jellegű vagy külső - motiváció esetén a viselkedés motivációjában valamilyen cél elérése vagy külső tényező szerepel. A motiváció célja lehet pénz vagy más anyagi erőforrás, ugyanakkor szeretet vagy mások általi megbecsülés is. Az intrinz̨ik - önjutalmazó vagy belső - motiváció olyan belső hajlamot jelent, amely az újdonság és a kihívás keresésében nyilvánul meg, abból a célból, hogy a személy kiterjessze vagy gyakorolja képességeit, illetve hogy felfedezzen, vagy esetleg megtanuljon valamit. Szoros kapcsolatban áll a hatékonyság érzésével, a spontán érdeklődéssel vagy az explorációval. ${ }^{612}$

A megkérdezés második szakaszában egy PERMA-modell alapján összeállított kérdőívet alkalmaztam. Seligman PERMA-modellje szerint az egészséges, jóllétet biztosító élet öt különböző komponensből áll. A pozitív érzelmek, boldogság komponenshez tartozik a pozitív érzelmi átélések gyakoriságának növelése, a bizalom kiépítése és fenntartása, az

\footnotetext{
${ }^{607}$ SPECTOR, Paul E.: Job satisfaction: Application, assessment, causes, and consequences. Sage, Thousand Oaks, 1997. p. 2.

${ }^{608}$ JUDGE, Timothy A. et al.: Job satisfaction: A cross-cultural review. In: ANDERSON, Neil et al.: (szerk.): Handbook of industrial, work \& organizational psychology, Sage, London, 2001. pp.25-52.

SPECTOR i. m. (1997) p. 2.

${ }^{609}$ GYÖKÉR i. m. (2001)

${ }^{610}$ DANTZKER, Mark L. (1997): Job satisfaction and community policing: A preview for future research? Police Chief, 1997. LX/V. 10. pp. 97-101.

DANTZKER, Mark L. - SurReTTE, Michael A.: Perceived levels of job satisfaction among police officers: A descriptive review. Journal of Police and Criminal Psychology, 1996. 11. 2. pp. 7-12.

${ }^{611}$ WeISS, Daniel J. et al.: Manual for the Minnesota satisfaction questionnaire. Minnesota studies in vocational rehabilitation, 1967. 22. pp. 1-120.

${ }^{612}$ RYAN, Richard M. - DECI, Edward L.: Intrinzic and extrinsic motivation: classic definitions and new directions. Contemporary Educational Psychology, 2000/25. pp. 54-67.
} 
együttműködés elősegítése, a kapcsolatok ápolása, a visszajelzések jelentősége, valamint a sikerek megünneplése. Az elmélyülés/aktivv elfoglaltság komponens jelenti a nyugodt munkavégzési körülményeket, a reális elvárásokat és értelmes feladatokat, az erôsség-alapú célokat és a megfelelési vágyat. A jó kapcsolatok komponens megfeleltethető a támogató és gondoskodó munkahelyi kultúrának, a pozitív közösségi élményeknek és a sokszínúség támogatásának. Az értelem/célok elemhez tartoznak az értelmes, önmagunkon túlmutató célok, az egyén értékes hozzájárulásának elismerése, továbbá az értékes munkavégzés motiváló és elkötelező hatása. A teljesitmény/sikerérzet komponens jelenti az autonóm munkavégzést, a sikerélmények hangsúlyozását és az egyéni ambíciók figyelését. Összességében a PERMA-modell magába foglalja mindazokat a tényezőket, melyek együttes jelenléte biztosíthatja a pozitív jóllétet és ennek része az egyén szubjektív tapasztalásai (érzelmei), az aktivitása (kapcsolatok kialakítására és fenntartására, értelem és célok keresésére, teljesítményre), valamint a környezettel való kiegyensúlyozott kapcsolata (támogató kapcsolatok, visszajelzések, szakmai siker és elismerés). Az ötödik elemmel bekerült a jóllét értelmezésébe az eredményekre, sikerre való törekvés is, mint a jóllét elérésének munkával kapcsolatos dimenziója. ${ }^{613} \mathrm{~A}$ PERMA-modell alapján összeállított, munkahelyi jóllétre vonatkozó kérdőív 35 itemből áll. ${ }^{114}$ A válaszadónak az egyes itemek alapján az elmélyülés, a pozitív érzelmek, a pozitív kapcsolatok, a teljesítmény és siker, az értelem és jelentés aspektusaira, valamint a munka negatív aspektusaira vonatkozóan kell az egyetértésének mértékét kifejeznie. A válaszadás egy ötfokú Likert-skálán történik (1 egyáltalán nem értek egyet; 5 - teljesen egyetértek).

A felmérés során az volt a célom, hogy feltárjam a hivatástudat, a motiváció, valamint a munkahelyi jóllét és elégedettség jelentőségét és intenzitását a Hajdú-Bihar Megyei Adó- és Vámigazgatóság személyi állományának vonatkozásában. A háttérváltozók esetében demográfiai kérdéseket fogalmaztam meg (nem, életkor, családi állapot, iskolai végzettség stb.), valamint a munkahelyi pozíciót és a NAV alkalmazásában eltöltött évek számát kértem megjelölni. A kvantitatív kérdőíves felmérésre 2021. április 15. és május 03. között került sor. Az adatgyűjtés során a megkérdezést következetesen, csak a NAV Hajdú-Bihar Megyei Adó- és Vámigazgatóság személyi állományának körében végeztem, kizárólag online formában, interneten keresztül. A kérdőív a Google Docs űrlapkészítő alkalmazással készült, a felmérésben a részvétel önkéntes volt. Az online kérdőív e-mailen keresztül került továbbításra és 33 fő kolléga töltötte ki a kérdőívet, akik közül valamennyien értékelhető választ adtak, ezért összesen 33 fó (n=33) a megkérdezett minta nagysága.

\section{Eredmények}

\section{A minta sqocio-demográfiai jellemzói}

A minta demográfiai jellemzőinél nemek, korcsoportok, családi állapot és munkahelyi pozíció szerinti kategóriákat állítottam fel, továbbá a NAV alkalmazásában eltöltött évek számáról is információkat kértem. A válaszadók közül a nôk aránya 72,7\%, legnagyobb arányban a 40-49 éves korosztály válaszolt kérdéseimre. A válaszadók több, mint kétharmada párkapcsolatban él, azaz 51,5\%-uk házas és 15,2\%-uk élettárssal él. A

\footnotetext{
${ }^{613}$ SELIGMAN, Martin: Flourish: A visionary new understanding of happiness and well-being. Free Press, New York, 2011.

${ }^{614}$ Kun Ágota et al.: Development of the Work-Related Well-Being Questionnaire Based on Seligman's PERMA Model. Periodica Polytechnica Social and Management Sciences, 2017. 25. 1., pp. 56-63.

https://doi.org/10.3311/PPso.9326
} 
megkérdezett kollégák 87,9\%-a ügyintéző és a válaszadók közel fele több mint húsz éve dolgozik a Nemzeti Adó- és Vámhivatalnál.

A kutatás során két háttérváltozó esetében csoportokat alkottam. A családi állapot háttérváltozó alapján két csoportot képeztem, a párkapcsolatban élők (házas vagy élettárssal élő válaszadók), valamint az egyedülállók csoportját (özvegy, nőtlen vagy hajadon, elvált és egyedülálló válaszadók). A Nemzeti Adó- és Vámhivatal alkalmazásában eltöltött évek száma háttérváltozó esetében két csoportot különítettem el, az egyik csoportba a 2-10 évig a Nemzeti Adó- és Vámhivatal alkalmazásában álló munkavállalók, a másik csoportba a legalább 11 éve a szervezetnél dolgozó munkavállalók tartoznak. A megkérdezett kollégák egyes háttérváltozók szerinti megoszlását az alábbi, 1. táblázat szemlélteti.

\begin{tabular}{|c|c|c|}
\hline $\begin{array}{l}\text { A minta bemutatása } \\
\qquad(N=33)\end{array}$ & & \\
\hline Demográfiai csoportok & $\mathbf{N}$ & $\%$ \\
\hline \multicolumn{3}{|l|}{ Nemek szerint } \\
\hline Férfi & 9 & $27,3 \%$ \\
\hline Nő & 24 & $72,7 \%$ \\
\hline \multicolumn{3}{|l|}{ Korcsoportok } \\
\hline 18-29 éves & 0 & $0,0 \%$ \\
\hline 30-39 éves & 10 & $30,3 \%$ \\
\hline 40-49 év & 17 & $51,5 \%$ \\
\hline $50-59$ éves & 5 & $15,2 \%$ \\
\hline 60 éves kor felett & 1 & $3,0 \%$ \\
\hline \multicolumn{3}{|l|}{ Családi állapot } \\
\hline Házas & 17 & $51,5 \%$ \\
\hline Élettárssal él & 5 & $15,2 \%$ \\
\hline Özvegy & 0 & $0,0 \%$ \\
\hline Nötlen/Hajadon & 2 & $6,1 \%$ \\
\hline Elvált & 4 & $12,1 \%$ \\
\hline Egyedülálló & 5 & $15,2 \%$ \\
\hline \multicolumn{3}{|l|}{ Munkahelyi pozíció } \\
\hline Ügyintéző & 29 & $87,9 \%$ \\
\hline Osztályvezető & 2 & $6,1 \%$ \\
\hline Főosztályvezető-helyettes, igazgatósági & & \\
\hline fóosztályvezető, igazgatóhelyettes & 2 & $6,1 \%$ \\
\hline \multicolumn{3}{|c|}{ A NAV alkalmazásában eltöltött évek száma } \\
\hline 2 évnél rövidebb időtartam & 0 & $0,0 \%$ \\
\hline 2-5 év & 2 & $6,1 \%$ \\
\hline 6-10 év & 9 & $27,3 \%$ \\
\hline $11-15$ év & 6 & $18,2 \%$ \\
\hline 16-20 év & 1 & $3,0 \%$ \\
\hline 20 évnél hosszabb időtartam & 15 & $45,5 \%$ \\
\hline
\end{tabular}

1. táblázat

Forrás: Saját adatfeldolgozás, 2021 


\section{Hipotézisvizsgálatok.}

A munkahelyi motivációval és hivatástudattal, a szervezeti elkötelezettséggel, továbbá a munkahelyi elégedettséggel és jólléttel összefüggésben két kérdőívet alkalmaztam feltáró kutatásom során. A Minnesota Elégedettségi Kérdốviben 20 item szerepel és az adott itemek alapján két jellemző munkahelyi tényezőkből álló skála különíthető el, amelyek az intrinzik és extrinzik munkahelyi tényezők. A PERMA-modell alapján összeállitott kérdöívben 35 item szerepelt, amely itemek alapján öt különböző skála különíthető el: elmélyülés, pozitív érzelmek, pozitív kapcsolatok, teljesítmény és siker, értelem és jelentés, valamint a munka negatív aspektusai. A célom annak megállapítása volt, hogy létezik-e összefüggés az egyes háttérváltozók és az adott itemekből képzett skálák között. Ennek érdekében a jelen felmérés során négy hipotézist fogalmaztam meg.

\section{Az elsö hipotézis}

$\mathbf{H}_{1}$ : A családi állapot befolyásolja a munkahelyi jóllétet a Nemzeti Adó- és Vámhivatal Hajdú-Bihar megyei Adó- és Vámigazgatóság munkavállalóinak körében is.

A PERMA-modell alapján összeállított, munkahelyi jóllétre vonatkozó kérdőív 35 itemének segítségével a válaszadók az elmélyülés, a pozitív érzelmek, a pozitív kapcsolatok, a teljesítmény és siker, az értelem és jelentés, illetve a munka negatív aspektusaira vonatkozóan fejezték ki egyetértésük mértékét a mindennapi munkájukra gondolva. Összességében megállapítható, hogy minden skála mentén nagyobb az átlaguk a párkapcsolatban élőknek, mint az egyedül élőknek, kivéve a munka negatív aspektusait, ahol az egyetértés értékelése fordított értelmezésben jelenik meg (2. táblázat). Ez a tény, vagyis hogy a párkapcsolatban élők átlagértéke minden a nyolc skála esetén nagyobb elégedettséget tükröz, szignifikanciaként is értelmezhetô, mert amennyiben ez a véletlen műve lenne, ennek az esélye mindössze $\mathrm{p}=0,004$.

Az adatok skálánkénti összehasonlítása során kétmintás t-próbát alkalmaztam, amely azt vizsgálja, hogy két külön csoport esetében szignifikánsan különböznek-e egymástól az egyes skálák átlagai, a szignifikancia szint $\mathrm{p}=0,05$. A párkapcsolatban élők és az egyedülállók csoportjainak átlagértékeit összehasonlítva az elmélyülés, a pozitív érzelmek, a pozitív kapcsolatok, a teljesítmény és siker, az értelem és jelentés, illetve a munka negatív aspektusainak skálái mentén két skála bizonyult szignifikánsnak. Ez a két skála az elmélyülés $(\mathrm{t}(31)=2,2 \mathrm{p}=0,035)$, valamint az értelem és jelentés $(\mathrm{t}(31)=2 \cdot 3, \mathrm{p}=0,03)$. Összességében tehát a $\mathrm{H}_{1}$ hipotézis részben beigazolódott.

A PERMA-modell itemei által meghatározott csoportok (komponensek) átlagát a családi állapot háttérváltozó (párkapcsolatban élők és egyedülállók) vonatkozásában az alábbi, 2. tábláą szemlélteti. 


\begin{tabular}{|c|c|c|c|}
\hline \multicolumn{4}{|c|}{$\begin{array}{c}\text { Skála átlagok a családi állapot szerinti } \\
\text { csoportokban }\end{array}$} \\
\hline & $\begin{array}{l}\text { Családi } \\
\text { állapot }\end{array}$ & $\mathrm{N}$ & Átlag \\
\hline \multirow[t]{2}{*}{ Intrinzik } & párban él & 22 & 44,09 \\
\hline & egyedül él & 11 & 37,82 \\
\hline \multirow[t]{2}{*}{ Extrinzik } & párban él & 22 & 20,14 \\
\hline & egyedül él & 11 & 17,36 \\
\hline \multirow[t]{2}{*}{ Elmélyülés } & párban él & 22 & 22,14 \\
\hline & egyedül él & 11 & 17,36 \\
\hline \multirow[t]{2}{*}{ Pozitiv érzelmek } & párban él & 22 & 19,27 \\
\hline & egyedül él & 11 & 18,00 \\
\hline \multirow[t]{2}{*}{ Pozitiv kapcsolatok } & párban él & 22 & 21,73 \\
\hline & egyedül él & 11 & 19,91 \\
\hline \multirow[t]{2}{*}{ Teljesítmény, siker } & párban él & 22 & 19,45 \\
\hline & egyedül él & 11 & 18,55 \\
\hline \multirow[t]{2}{*}{ Értelem, jelentés } & párban él & 22 & 25,95 \\
\hline & egyedül él & 11 & 22,55 \\
\hline \multirow[t]{2}{*}{ Munka negativ aspektusai } & párban él & 22 & 14,82 \\
\hline & egyedül él & 11 & 15,45 \\
\hline
\end{tabular}

2. táblázat

Forrás: Saját adatfeldolgozás, 2021

\section{A második hipotézis}

$\mathbf{H}_{2}$ : A Nemzeti Adó- és Vámhivatal alkalmazásában eltöltött évek számával csökken a munkahelyi jóllét.

Kétmintás t-próbával hasonlítottam össze a két csoport - a 2-10 évig a Nemzeti Adó- és Vámhivatal alkalmazásában álló munkavállalók és a legalább 11 éve a szervezetnél dolgozó munkavállalók - jellemzőit minden skála mentén, a szignifikancia szint $\mathrm{p}=0,05$. A skálák a Minnesota Elégedettségi Kérdőiv és a PERMA-modell alapján összeállított kérdőív egyes komponenseit jelentik, azaz intrinzik és extrinzik munkahelyi tényezők, elmélyülés, pozitív érzelmek, pozitív kapcsolatok, teljesítmény és siker, értelem és jelentés, továbbá a munka negatív aspektusai. A Nemzeti Adó- és Vámhivatal alkalmazásában eltöltött évek száma szerinti csoportok skála átlagait az alábbi, 3. táblázat szemlélteti. 


\begin{tabular}{|c|c|c|c|}
\hline \multicolumn{4}{|c|}{$\begin{array}{c}\text { Skála átlagok a NAV alkalmazásában eltöltött idő } \\
\text { szerinti csoportokban }\end{array}$} \\
\hline & $\begin{array}{l}\text { Hivatali évek } \\
\text { száma }\end{array}$ & $\mathrm{N}$ & Átlag \\
\hline \multirow[t]{2}{*}{ Intrinzik } & 2-10 év & 11 & 42,73 \\
\hline & 10 év fölött & 22 & 41,64 \\
\hline \multirow[t]{2}{*}{ Extrinzik } & $2-10$ év & 11 & 20,45 \\
\hline & 10 év fölött & 22 & 18,59 \\
\hline \multirow[t]{2}{*}{ Elmélyülés } & $2-10$ év & 11 & 22,55 \\
\hline & 10 év fölött & 22 & 19,55 \\
\hline \multirow[t]{2}{*}{ Pozitiv érzelmek } & $2-10$ év & 11 & 19,55 \\
\hline & 10 év fölött & 22 & 18,50 \\
\hline \multirow[t]{2}{*}{ Pozitiv kapcsolatok } & $2-10$ év & 11 & 22,00 \\
\hline & 10 év fölött & 22 & 20,68 \\
\hline \multirow[t]{2}{*}{ Teljesítmény, siker } & 2-10 év & 11 & 19,82 \\
\hline & 10 év fölött & 22 & 18,82 \\
\hline \multirow[t]{2}{*}{ Értelem, jelentés } & 2-10 év & 11 & 26,00 \\
\hline & 10 év fölött & 22 & 24,23 \\
\hline \multirow[t]{2}{*}{ Munka negativ aspektusai } & $2-10$ év & 11 & 12,64 \\
\hline & 10 év fölött & 22 & 16,23 \\
\hline
\end{tabular}

3. táblázat

Forrás: Saját adatfeldolgozás, 2021

A munka negatív aspektusai esetén szignifikáns eltérés mutatkozik, annak a csoportnak, amely munkavállalói legalább 11 éve dolgoznak a szervezetben, szignifikánsan magasabb a skála átlaga $(\mathrm{t}(31)=2,01, \mathrm{p}=0,046)$. Ugyanakkor ez a munkavállalói csoport a többi skála esetén is átlagosan kevésbé volt elégedett és átlagértékük minden skála esetén alacsonyabb, mint a 2-10 éve a szervezetnél dolgozók átlagértékei (3. táblázat). Az a tény, hogy a legalább 11 éve a hivatalban dolgozók átlagértéke minden a nyolc skála esetén kisebb elégedettséget tükröz, szignifikanciaként is értelmezhető, mint az előző hipotézis esetén: amennyiben ez a véletlen múve lenne, ennek az esélye mindössze $\mathrm{p}=0,004$, tehát a $\mathrm{H}_{2}$ hipotézis részben beigazolódott.

Az elemzés alapján fordulópontnak a 10 éves hivatali munkaviszony elérésének időpontja tekinthető. Összességében a legalább 11 éve a szervezetnél dolgozó, egyedülálló munkavállalók számítanak fokozottan veszélyeztetettnek a munkahelyi jóllét szempontjából. Ezen hivatali dolgozók esetében csökken a munkahelyi motiváció, valamint a munka negatív aspektusait is fokozottabban élik meg, amely a fizikai egészségi állapotukra is negatívan hathat.

\section{A barmadik hipotézis}

$\mathbf{H}_{3}$ : Az egyes munkahelyi jóllét tényezőkkel nem egyforma mértékben elégedettek a hivatali munkavállalók, léteznek jobban és kevésbé preferált munkahelyi jóllét tényezők. 
A PERMA-modell alapján összeállított munkahelyi jóllét témájú kérdőív öt skálájának elmélyülés, pozitív érzelmek, pozitív kapcsolatok, teljesítmény és siker, értelem és jelentés egy itemre számított átlagait hasonlítottam össze egy szempontos varianciaanalízissel, hogy megállapítható legyen, létezik-e szignifikáns eltérés az egyes skálák között (a szignifikancia szint $\mathrm{p}=0,05)$. A célom annak eldöntése volt, hogy bizonyos munkahelyi jóllét tényezôkkel a munkavállalók elégedettebbek-e, illetve lehet-e ezekből az átlagokból egy jellemző profilt megrajzolni. A választ az egyszempontos varianciaanalízis ismételt méréses változata adja meg, ahol a független változó öt értéke az öt különböző skála. Összességében az egyes átlagértékek között szignifikáns eltérés mutatkozik $(\mathrm{F}(4,29)=20,79, \mathrm{p}<0,001)$, amely átlagértékek egy profilt rajzolnak meg, tehát a $\mathrm{H}_{3}$ hipotézis beigazolódott. A PERMA-modell itemjei által meghatározott skálák átlagértékeit az alábbi, 1. ábra szemlélteti.

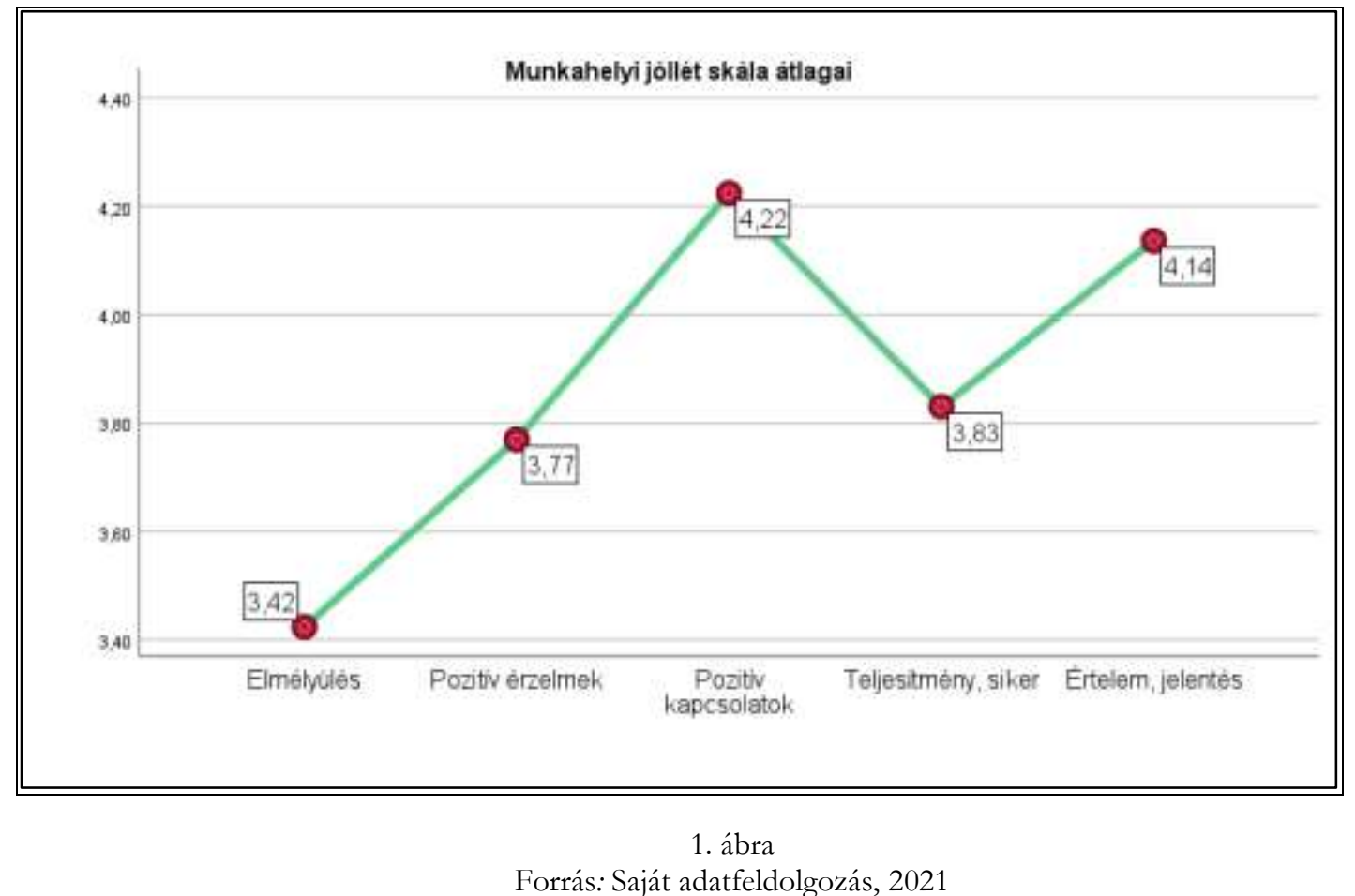

A PERMA-modell egyes itemjei esetében a válaszadás egy ötfokú Likert-skálán történt (1 egyáltalán nem értek egyet; 5 - teljesen egyetértek). Az egyes skála átlagok között kiemelkedik a pozitív kapcsolatok skála (átlagértéke: 4,22), mely arra utal, hogy a munkavállalóknak fontosak a közösségi élmények és a társas kapcsolatok a munkahelyen. Szintén magasabb, 4,14 átlagértéket mutat az értelem és jelentés skála, mely az értékes, jelentésteli munka motivációját, valamint az egyéni tevékenységek elismerését jelenti a munkavállalók számár a munkavégzés során. Összességében a legalacsonyabb átlagérték az elmélyülés skálához köthető (átlagértéke: 3,42) a szervezetben, mely skálához a képességek és kihívások összhangja, a belső motiváció és a megfelelési vágy tartoznak.

\section{A negyedik hipotézis:}

$\mathbf{H}_{4}$ : Az egyes skálák átlagértékei által megrajzolt profil függ a munkavállaló családi állapotától.

A vizsgálat során kétszempontos varianciaanalízist alkalmaztam, amely több független változó hatásának és kereszthatásának vizsgálatát teszi lehetôvé. Az egyik független változó most is a skála - elmélyülés, pozitív érzelmek, pozitív kapcsolatok, teljesítmény és siker, értelem és jelentés, amely személyen belüli faktor; a másik pedig a 
munkavállaló családi állapota - mely személyek közötti faktor. Ez utóbbi esetében a már korábban említett két csoport - párkapcsolatban élők és egyedülállók - jellemző értékeit vizsgáltam. A vizsgálat arra irányult, hogy az egyes skála - elmélyülés, pozitív érzelmek, pozitív kapcsolatok, teljesítmény és siker, értelem és jelentés - átlagok által megrajzolt profil összefügg-e a családi állapottal. A kétszempontos varianciaanalízis eredményeképpen az interakció szignifikánsnak bizonyult, azaz az öt különböző skála esetén nem azonos a párkapcsolatban és az egyedül élők átlagos értékei közötti különbség. A párkapcsolatban élő munkavállalók átlagértékei minden esetben magasabb értékeket mutatnak az egyedülálló munkavállalók átlagértékeinél. Két skála, az elmélyülés, illetve az értelem és jelentés esetében a párkapcsolatban élők és az egyedül élők átlagos értékei közötti eltérés kiugróan magas. A párkapcsolatban élő dolgozók esetében az elmélyülés skála átlagértéke 3,69, az egyedülálló munkavállalók ezt a területet átlagosan 2,89-re értékelték. Az értelem és jelentés skála átlagértéke a párkapcsolatban élő munkavállalók esetében 4,33, ugyanakkor az egyedülálló dolgozók esetében 3,76 az átlagérték. Összességében a $\mathrm{H}_{4}$ hipotézis beigazolódott. A munkahelyi jóllét skála átlag értékeit a családi állapot függvényében az alábbi 2. ábra szemlélteti.

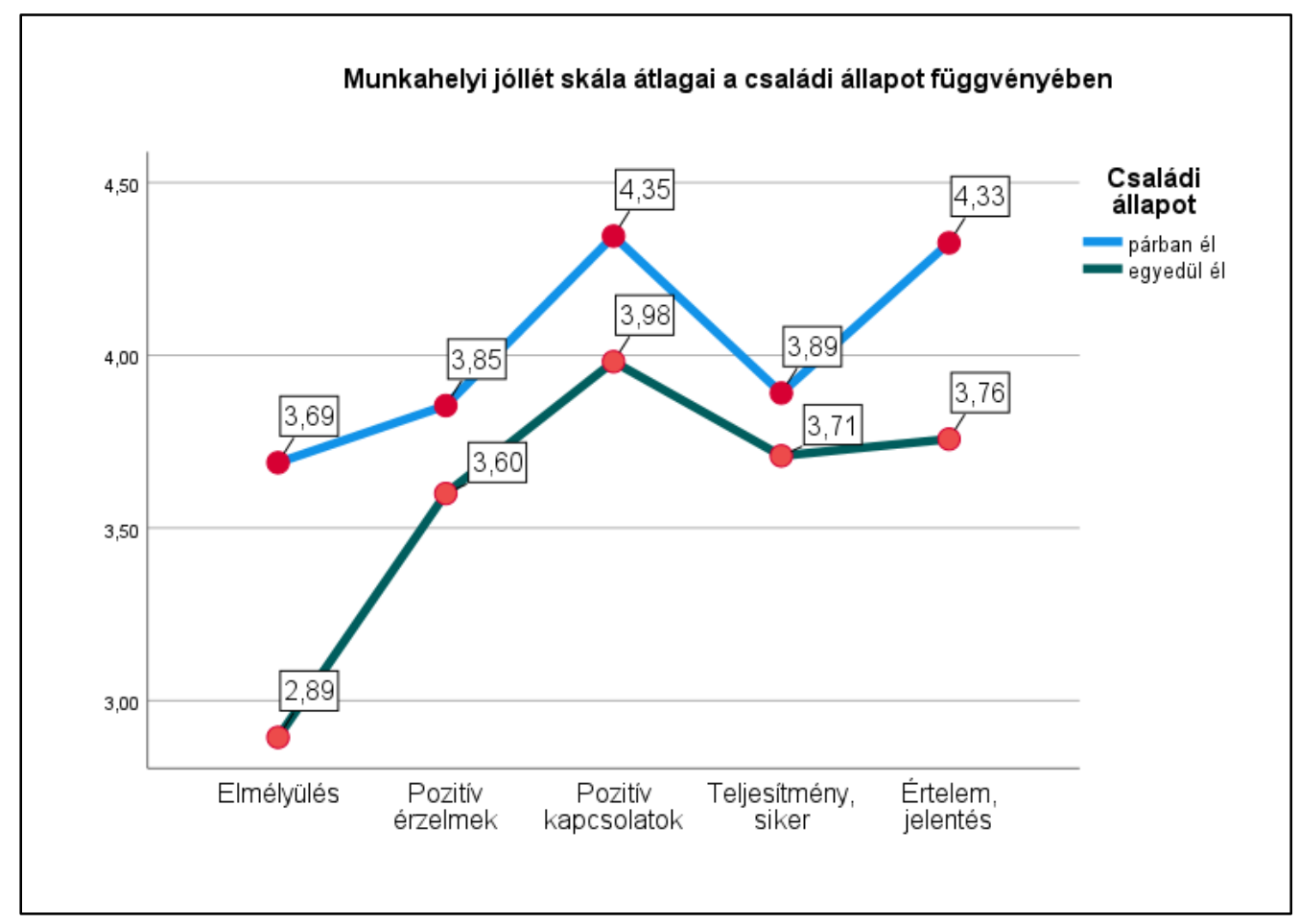

2. ábra

Forrás: Saját adatfeldolgozás, 2021

\section{Következtetések és javaslatok}

Egyetértek Szlávicz véleményével, miszerint a munkavállaló valódi elégedettsége és örömteli munkavégzése érdekében olyan munkára van szükség, amelyet a dolgozó szeret, és minden nap szívesen végez. Emellett természetesen időnként lehetnek nehezebb, kedvetlenebb és fáradtabb periódusok, de összességében olyan munkára van szükség, amely pozitív dologként reprezentálódik az ember érzelmi és fogalmi rendszerében. Ha a munkavállaló érzi, hogy megbecsülik, illetve biztosított számára a fejlődés és az előmenetel lehetôsége, 
valamint egyúttal anyagilag és emberileg biztonságban érzi magát, akkor egy olyan közeg veszi körül, amely a dolgozói elégedettség alapja lehet. ${ }^{615}$

A kutatás során megkérdezett válaszadók több mint kétharmada párkapcsolatban él és a válaszadók közel fele több mint húsz éve dolgozik a Nemzeti Adó- és Vámhivatalnál. A párkapcsolatban élôk és az egyedülállók csoportjainak átlagértékeit összehasonlítva két skála, az elmélyülés, valamint az értelem és jelentés bizonyult szignifikánsnak. A Nemzeti Adó- és Vámhivatal alkalmazásában eltöltött évek száma esetén fordulópontnak tekinthető a tíz éves hivatali munkaviszony elérésének időpontja, a legalább tizenegy éve a szervezetnél dolgozó, egyedülálló munkavállalók számítanak fokozottan veszélyeztetettnek a munkahelyi jóllét és elégedettség szempontjából. Az egyes munkahelyi jóllét tényezőkkel nem azonos mértékben elégedettek a hivatali dolgozók, az egyes skála átlagok között kiemelkedik a pozitív kapcsolatok skála, mely azt jelzi, hogy a munkavállalóknak fontosak a közösségi élmények és a társas kapcsolatok a szervezetnél. A legalacsonyabb átlagérték az elmélyülés skálához köthetô, mely a képességek és kihívások összhangját, a belsô motivációt és a megfelelési vágyat jelenti. A párkapcsolatban élő munkavállalók átlagértékei minden skála esetében magasabb értékeket mutatnak az egyedülálló munkavállalók átlagértékeinél, és két skála - az elmélyülés, illetve az értelem és jelentés - esetében az eltérés kiugróan magas.

A munkahelyen akkor magasabb szintű az elkötelezettség, ha a dolgozók teljesen tisztában vannak a feladataikkal, a vezetôk bevonják a munkavállalót a vállalat életébe, illetve ha képesek a folyamatos megújulásra. A szervezetnek és a vezetőknek jutalmazni és támogatni kell a munkavállalókat azért, amit végeznek, mert ez az ösztönzés erősíti a szervezeti elkötelezettséget. ${ }^{616}$ Összességében a munkahelyi elégedettség és jóllét megvalósulásához számos tényező együttes jelenléte szükséges, többek a között megfelelő munkahelyi környezet és légkör, elismerés, megbecsülés, ösztönző és megfelelő színvonalú jövedelmezési rendszer, pozitív munkahelyi kapcsolatok, munkahelyi aktivitás és szakmai motiváció. A külső befolyásoló tényezők mellett azonban elengedhetetlen a munkavállaló egyéni, folyamatos törekvése a munkahelyi elégedettség és jóllét egyes elemeinek elérésére.

\section{Felhasznált irodalom}

[1] Bateman, Thomas - StRAsser, Stephan: A longitudinal analysis of the antecedents of organizational commitment. Academy of Management Journal, 1984. 21. pp. 95-112. https://doi.org/10.2307/255959

[2] Bullough, Robert V. - BAughman, Kerrie: First-year teacher eight years later. Teacher College Columbia University, New York-London, 1997.

[3] DANTZKER, Mark L. (1997): Job satisfaction and community policing: A preview for future research? Police Chief, 1997. LX/V. 10. pp. 97-101.

[4] Dantzker, Mark L. - SurretTe, Michael A.: Perceived levels of job satisfaction among police officers: A descriptive review. Journal of Police and Criminal Psychology, 1996. 11. 2. pp. 7-12. https://doi.org/10.1007/BF02803703

[5] Deutsch Szilvia et al: A jóllétet meghatározó tényezők vizsgálata egészségügyi szakdolgozók körében. Alkalmazott pszichológia. 2015/2. szám, pp. 49-71.

\footnotetext{
615 SZLÁviCz Ágnes: A „Dolgozó magyarok 2006” dolgozói elégedettség felmérés módszertani elemzése. Doktori értekezés, Szent István Egyetem Gazdálkodás és Szervezéstudományok Doktori Iskola, Gödöllő, 2010.

${ }^{616}$ EISEnBerger, Robert et al.: Perceived Organizational Support and Employee Diligence, Commitment, and Innovation. Journal of Applied Psychology, 1995. 75. 1. pp. 51-59.
} 
[6] Diener, Ed: Subjective well-being. Psychological Bulletin, 1984. 95. pp. 542-575. https://doi.org/10.1037/0033-2909.95.3.542

[7] DOMBI Alice: Tanári minta - mintatanár. APC Stúdió, Gyula, 1999.

[8] Eisenberger, Robert et al.: Perceived Organizational Support and Employee Diligence, Commitment, and Innovation. Journal of Applied Psychology, 1995. 75. 1. pp. 51-59. https://doi.org/10.1037/0021-9010.75.1.51

[9] Fowler, Susan: Motiváció magasabb szinten. HVG Kiadó Zrt., Budapest, 2014. p. 59.

[10] GYÖKÉR Irén: Humánerőforrás-menedzsment. Műszaki Könyvkiadó, Budapest, 2001. pp. 54-55.

[11] JUDGE, Timothy A. et al.: Job satisfaction: A cross-cultural review. In: ANDERSON, Neil et al.: (szerk.): Handbook of industrial, work \& organizational psychology, London: Sage, 2001. 2. pp. 25-52. https://doi.org/10.4135/9781848608368.n3

[12] KLEIN Sándor: Vezetés- és szervezetpszichológia. Edge 2000 Kft., Budapest, 2004. p. 345.

[13] Kun Ágota et al.: Development of the Work-Related Well-Being Questionnaire Based on Seligman's PERMA Model. Periodica Polytechnica Social and Management Sciences, 2017. 25. 1., pp. 56-63. https://doi.org/10.3311/PPso.9326

[14] MCCLELLAND, David Clarence: Human motivation. New York, NY: Scott Foresman, 1985.

[15] NAGY Antal: A hivatástudat és az etika oktatása. 1985. http://acta.bibl.uszeged.hu/18219/1/igytf tudkozl historica 1985 075-078.pdf (Letöltés+ ideje: 2021. április 28.).

[16] O'Reilly, Charles A. - Chatman, Jennifer: Organizational Commitment and Psychological Attachment: The Effects of Compliance, Identification and Internalization on Prosocial Behavior. Journal of Applied Psychology, 1986. 71. 3. pp. 492499. https://doi.org/10.1037/0021-9010.71.3.492

[17] PORTER, Lyman William et al.: Organizational commitment, job satisfaction, and turnover among psychiatric technicians. Journal of Applied Psychology, 1974. 59. pp. 603609. https://doi.org/10.1037/h0037335

[18] RYAN, Richard M. - DECI, Edward L.: Intrinzic and extrinsic motivation: classic definitions and new directions. Contemporary Educational Psychology, 2000/25. pp. 54-67. https://doi.org/10.1006/ceps.1999.1020

[19] Seligman, Martin: Flourish: A visionary new understanding of happiness and wellbeing. Free Press, New York, 2011.

[20] Spector, Paul E.: Job satisfaction: Application, assessment, causes, and consequences. Thousand Oaks, CA: 1997. https://doi.org/10.4135/9781452231549

[21] SZLÁviCZ Ágnes: A „Dolgozó magyarok 2006” dolgozói elégedettség felmérés módszertani elemzése. Doktori értekezés, Szent István Egyetem Gazdálkodás és Szervezéstudományok Doktori Iskola, Gödöllő, 2010.

[22] VÁRINÉ SZILÁGYI Ibolya: Fiatal értelmiségiek a pályán. Akadémiai Kiadó, Budapest, 1981.

[23] WADDELL, Gordon - BURTON, A. Kim: Is work good for your health and well-being? TSO, London, 2006.

[24] WARR, Peter: Work, unemployment, and mental health. Clarendon Press, Oxford, 1987.

[25] WeIss, Daniel J. et al.: Manual for the Minnesota satisfaction questionnaire. Minnesota studies in vocational rehabilitation, 1967. 22. pp. 1-120. https://doi.org/10.1037/t08880$\underline{000}$ 
[26] Zimbardo, Philip et al.: Pszichológia mindenkinek. Pearson Education, Inc., 2017. pp. 11., 13-14.

\section{Lektor}

Máth János, Dr., Ph.D. egyetemi docens, Debreceni Egyetem Pszichológiai Intézet, janosmath@gmail.com 